\title{
NUTRITIONE PLANTARUM
}

CUjus

PARTEM PRIMAM

VENIA EXP. FAC. MED. UPSAL.

PR E S I D E
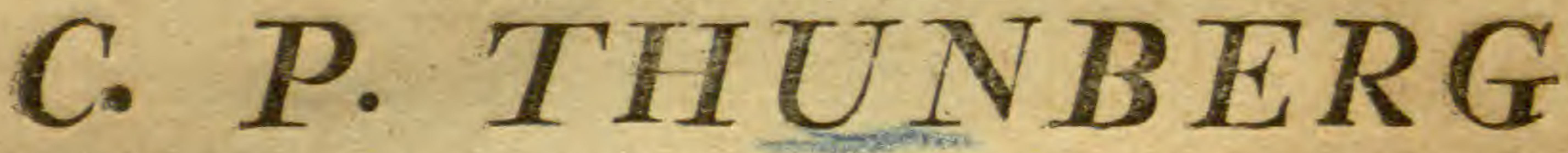

COMMENDATORE REG ORD. DE WASA,

Med. Doct. Prof. Mad. et Bot. Reg. et Okd, Reg Coll. Sanit. Memb. Hon. Acad, Casar, Petropol. ei Nat, Curios, Reg, Scignt, lond. Holm. Agric. Med. et Evang. Societ. Oecon. upsal. Patr. Hotm, et Civ. Orcon, Finl. Honor. Wermel. Westm. Calm, et órebr. Berol. Nat. Scrut. Paris. Hafn, Moscou, et Halens. Hist. Nat. Goren K. Phil ad, Lund. Harlem. Amsteld. Oecon. et Inst. Latt. Zeland. Nrdrosiens. turicens Imnens, Linn. Londin. Reg. Scient. Pays. et Phyto. grapt, Górtingens. Scientr. Gothob. Munach. Ertang. Whtter. Nanciens. Marpurg. Med. Paris. Emol. Monspel. Med Mistritens, Med. ex Nat, Srudios, Enimburg. fi Petrop. Medico Chir. Membra ngc non Acad. Scient. Paris et Institut. Nation, Monspeliens. Agricult. Paris, Medic, Londin, Scandinav, Fiorentin. et Batayin, Ind, Or.

Correstond.

P. P.

JOHANNES JOHANSSON.

CALMARIENSIS.

IN AUDITOR, BOTANICO D. III, JUNII MDCCCXIX,

H. A. M. S.

Mo. Bot. Garden.

1896.

UPSAL I E,

EXCUDEBANT REGIAE ACADEMIAE TYPOGRAPHI. 
MONSIEUR

IVAGIV. J. DE RYÖRINSTYERIVA MAJOR-GENERAL ET CHEVALIER DE L'ORDRE DE L'EPEE ET

à MADAME LA GENERALE

EIISE DE BYÖRIVSTYZERNA,

\section{NÉE NILSON,}

SON EPOUSE.

MONSIEUR ET MADAME.

L'occasion de vous donner un temoignage public de la réconnoissance, que je vous dois, m'est trop précieuse pour ne pas la saisir avec empressement. Veuillez done me permettre, Monsieur \& Madame, de faire paroitre sous Vos auspices la dissertation ci-jointe \& de Vous temoigner en même tems le regret, que je ressens de ne pouvoir donner plus d'éclat à mon hommage.

Je suis avec le plus profond resped,

Monsieur \& Madame,

votre très humble.

\& très obéissant serviteur

J. JOBANSSON. 
VIRO

AMPLISSIMO ATQUE CELEBERRTMO

DOMINO

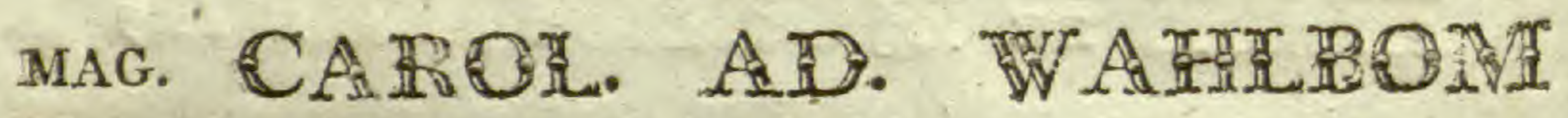

S. S. THEOL. DOCT. REVERENDISSIMO,

PROFESS. ET LECT. ELOQU. CALM, MERITISSIMO,

\section{Fautori Optimo}

Sacrum

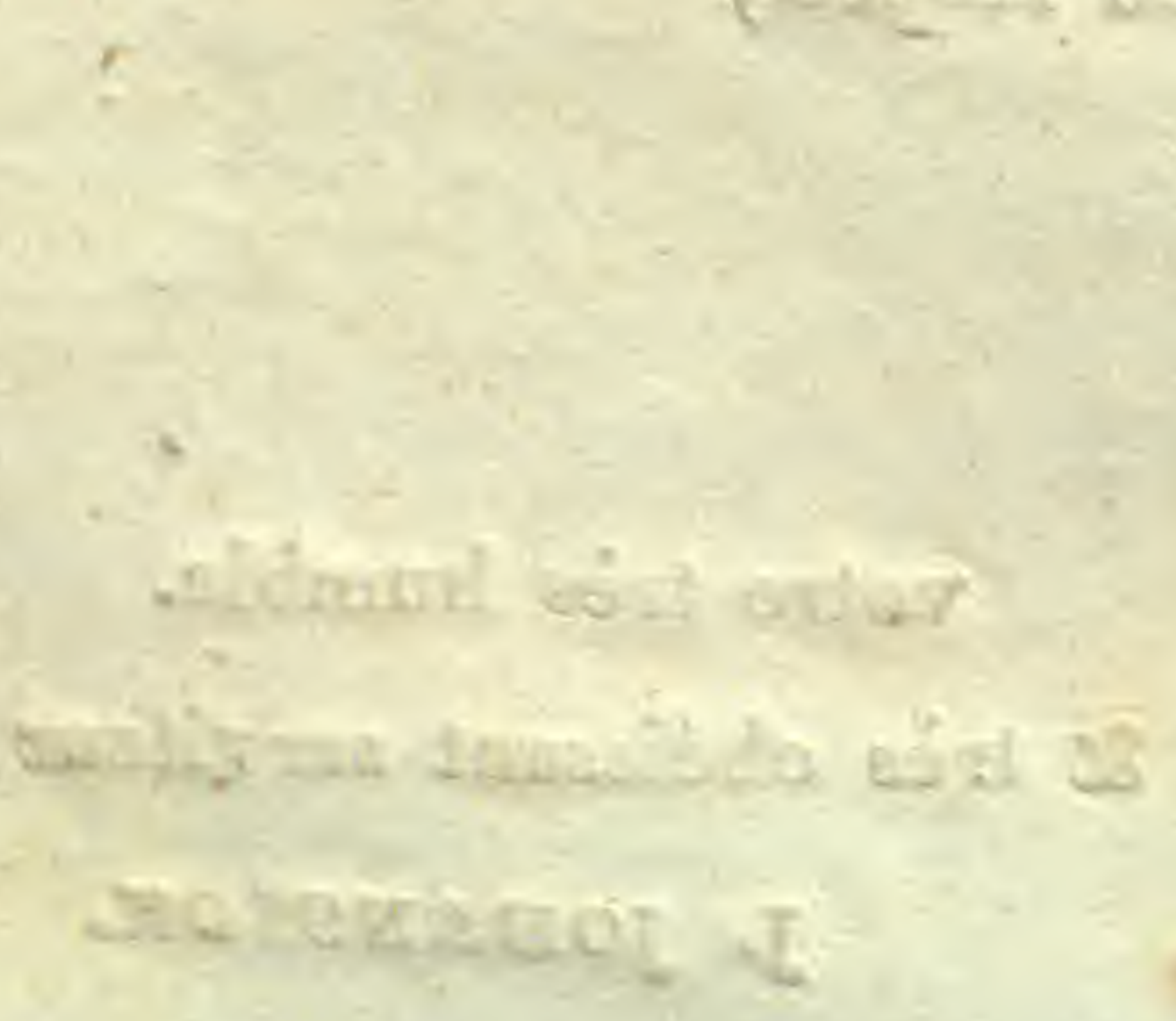

จoluit, debuit

J. JOHANSSON: 


\section{$\mathrm{OM}$}

\section{W $\ddot{A} X T E R N A s$ \\ F ÖDO- $\mathrm{A} M N$ EN. \\ 2. 5 .}

Jordens yta gifver i allmänhet ât hela växt-riket et sákert fäste. Ganska fâ växter lefva pả vatten-ytan med i vatnet nedhängande rötter. Sällan gå nâgre växter med sine rütter pả djupet, Merendels utsprida sig rötterna $\mathbf{i}$ den obfa jordskorpan, utur hvilken de hämta sin föda. Denna jordskorpa ấr olika beskaffad till sin fasthet och blandning, och sâledes olika tjänlig till både fäste och till näring for särskilda vàxcarter. Haraf upkommer växters olika hemvist uti olika. jordmoner.

Wäxterna kunna väl utur luften hämta något till sin näring och igenom insugandet af en viss fucktighet bibehálla sig, äfven en längre tid, utan att uttorka, sảsom omkring Cairo i Egypten, der landet blott en gång årligen vattnas af Nilens flöde: der det aldrig regnar, och der träilen, under de fläste mânader af âret, måste âtnöjas med nătternas kyliga ångor. Den sanningen är dock onekelig, att de fläste växt-rikets alster häınta sin förla ur jorden, efter hvilkens beskaffenhet, samt ymnigare eller ringare förrâd af fỏdoäm. ne, växtens utvickling, frodighet och fortskyndande till sitt mâl hufvudsakeligen beror. När frỏet blifvit lagdt uti jorden, svälla Cotyledones, spricka sedan, upskjuta och tränga sig 


\section{) 2(}

fram genom jordytan. Den fina trâdilka roten sprider sỉg derefter vidare ut under jorden och upsuper den närings.saft, som ofvan jorden skall utveckla efter hand alla offriga delar, blad, grenar, blommor och frukt. Raten, ehura ol:ka till utseende, skall nästan ensam utur jorden uphämta det födo. amne, hvilket vidare uti barkens âdror fürdt till den upvästa stammen skall frambringa sâ mảnga olika delar och gif. va ämne till så talrika, som särskilda delars framkomst och tillvâxt.

Für att kunna bestämma Västernas fodo ämnen, är nödigt, att vàl känna sjelfva jordarterna, neml. Lera, Sand och Kalk, samt deras tillsatser utaf Mat-jord, Vatten, Salter och Oljor, jemte det, som Luft, Lyse och. Värme till Växternas till văxt bidraga.

5- Da Växterne blifvit af Skaparen inquarterade under 6. lika himmels strek, sả är kunskapen om det klimat, som fordras och den jordmon, som är tjänligast för hvarje växt, icke likgiltig för en landtman och Trägảrdsmästare. Ju när. mase man följer Naturens egen gåńg, desto bättre måste hvarje odlings företag lyckas.

Lüran om jordarterne har derföre brifvit ansedd sâsom en vigtig kunskapsgren för Landtbrukare. Och jordblandnin. gar hafva ansets medfüra mycken nytta, emedan dé utsådde frön deruti alltid kunnat finna nảgot, för sin natur tjänligt füdo ämne. Den ena jord-arten har ock tillika förbättrat den andtas olägenheter. Att utstaka den jord mon, som hvarje yäxt hälst äskar, har väl utaf Skriftställare blifvit fürsök g 


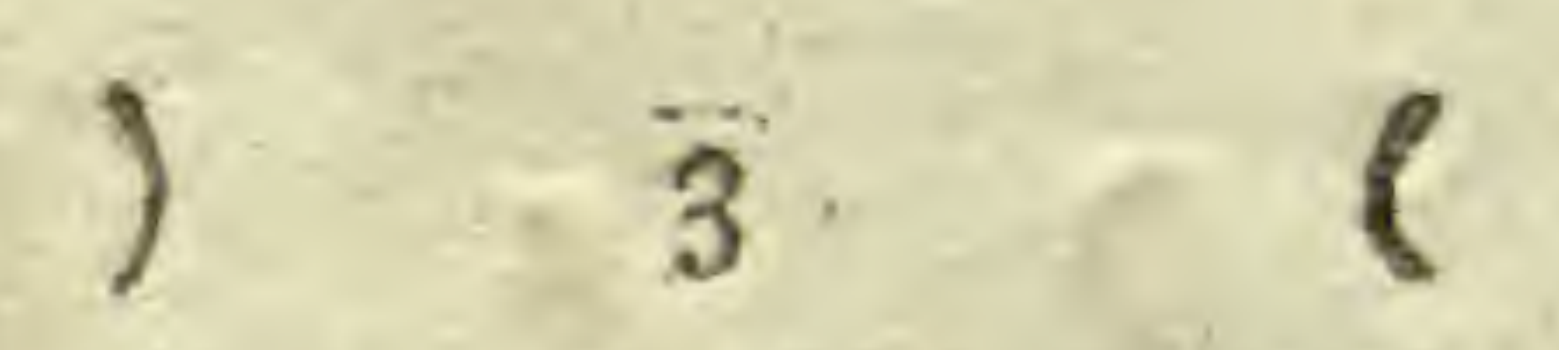

men ingen särskild afhandling, i anseende till hela västriket, har härtills blifvit bearbetad.

\section{2. §.}

Leran har vanligen blifvit ansedd för starkare, bättre och fordelaktigare, än Sand och Kalk-jord. Dess egenskap är, alt gifva ett säkrare fäste ât växternes rỏtter. Den super till sig vatten och bibehâller det längre, innan det kan antingen djupare draga sig ned, eller i lufien bortdunsta. Deremot hârdnar den af torka och spricker i mânga terningar sinder, sâ att rötterna blottas och torka. Om den i och för sig sjeff gifver nảgot fodeämne ảt Växierne, kan med alt skäl tviflas. Atminstone blir det adeles omàrkeligt. Ler. $\AA$ krar, som äga ingen tiiblandning af Marjord, äro derföre aldeles magra. Likasom vatnet uti Ler jord längre quarhảlles, sả förflyger icke eller den dermed blandade Matjordon sả hastigt, som uti Sand-jord. Lexans hârdhet vâlè , att en sâdan Åker icke, utom vid god must kan köras. Köres den vid dâlig must, upkomma stọra kokor, som snart hảrdna, sedan svårligen söncerbrâkas och skada åkren. En stark ler-jord är otjänlig för alla de växter, hvars rot är en Lók, (bulbug) Eller knöl (ruber). Sảdane rôtter, om de ligga något under jord ytan, kun. na der icke utvidga sig eller vinna någon storlek och såIunda aldrig lëna odlarens möđa. I samma mởn zỏdsel, spân, Mergel, sand eller kalk tillsättas, kan den väl fơrbättras, men denna förbittring är då icke lerans förtjenst för en. större afkastning Poräter kunna väl växa uti en med sand. och godsel upblandad lera, saint blifva goda och válsmakelige; men aldrig kunna de blifva stora, eller bringas till ym- 


\section{) $4(\mathrm{C}$}

nighet. Deremot kunna Kål-rötter, ja äfven Rofvor blifva mera gifvande, och det af den orsaken, att bảda dessa rot. frukter văxa uti sjelfva jordytan, ofta till hälften upskjutne öfver densamma, Ju renare blả-lerau befinnes, desto mindre föda äger den för växterne, och om den äs aldeles ren, måste ingen växt kunna näras deraf. Det är sålunda troligt, att Leran ren och utan tillsatts icke lämnar något födo ämne för Växterne, ehuru en ansenlig mängd växter gerna trifvas pả ler-jord, som likväl altid måste hysa större eller mindre mängd af nâgon annan tilblandning, hvilken förmår gifva näring. Leran förenar sig latteligen med alla jordarter, och befinnes altid närmare ytan dermed mer eller mindre späckad. Pả djupet blir den mera fri frân tilblandning, å̀ minstone af matjord. De rön, som med ren Lera anställas, skola befästa denna Sanning. Men sådane rön böra anställas med urskillning; ty en växt kan fortkomma uti ren lera af det vatten, hvarmed den vatunas, likasom en ört kan växa uti ren filspån och fulkomligt ren sand. Ja frön logde på en linnelapp, ùtan all slags jord, kunna genom vattning gro och till en tid växa, änskönt deras rötter äga ingenstädes fäste.

$$
\text { 3. } \S \text {. }
$$

Sandén räknas i allmänliet för mager. Uti fulkomfigut sen Sand fortkommer äfven sâ litet någon växt, som uti ren I.era, Nog tyckas vissa växter starkt motsäga denna förmo. đan, såsom Elymus arenarius, Carex arenaria och några andra, hvilka fortkomma uti den magraste flygsand, för att hämma den; men dessas rötter gả antingen djupt ned, der fuckrighet finnes, eller krypa de vidt omkring. Utom dess äs Vüxternes törst olika, somlige, sảsom Balsaminen, måste val- 


\section{) 50}

nas ganska ymnigt, då succulenta Växter kunna uti Africas ödemarker, utan vaten bärga sig flere månader och flere år, utan att dö eller förlora sin gronings $\mathrm{kraft}$.

Sand jorden är alt:d lös. Den kan arbetas efter behag och klimpar sig ieke tillsammans uti kokor; men sanden släpper lätt igenom det regn, som faller, och torkar snarare. Af Solens strảlar tager den starkare hetta, och sägez derforre, vid lângvarig torka, bränna växten. Sädet uti sandjord skyndar gemenligen suarare till mognad, under torra âr, med lågare halm och smärre ax. Uti sand artas bättre rot.frukter och då de der lätt kunna utvidga sig ât alla sidor, gifva de ofta en ymnig afkastning. Hushảllare i allmänhet erkänna, att sandjord bör oftare gödas och att gödningen ej äger länge bestând, emedan Matjorden till en del nedsjunker pâ djupet, till en del af hettan förtorkas. Likasom Leran göres lucker genom påford Sand, sả kan Sand-jorden förbăttras med pâförd Lera, utan att antingen Sanden eller Leran derföre gifva mexa ämnen till föda.

\section{4. §.}

Ren Kalk är sannolikt lika så litet födoämne för Växt. riket, som ren Iera och Sand. Blandad till Lera, förbättrar den Lerjorden. Mergel anses derfore fòr ett gödnings ämne på Åkern, hvilken deraf blir losare och tjäuligare för Växternas rötter, att kunna kringsprida sig deruti. Kalken äger stark dragningskraft till de uti luften befintelige Syror och kan således, áfven $\mathrm{i}$ det afseendet blifva nyttig, att tillskynda Vaxterne elt fudande ämne, eller att bereda det, som jora 


\section{$5 \quad 6$}

đên äger; till den egenskapen, att kunna ingâ och kringde. las uti dess finaste ådror.

5. \$.

Mat-jord kallas den Mull, som genom förruitnelse upkommer af Vüxter, samt spillning efter de djur, som lefva utaf Växter. Spiłlning efter Rof djur dager sällan och nyttjas äfven sällan eller aldrig. Katten och Hunden nedgräfva sitt Album græcum, som luktar fränt och begagnas icke vid nảgon odling. Pecora eller den tama Boskapen och Jumenta, eller Hästen, och svinet gifva ymnig tillgång till denna mull, äfven som alla affallna blader, stjelkar och stammar af Yäxt.riket. Ju mustigare fioda Boskapen njuter, desto kraf. tigare gödsel lämnar Ladugårclen. Grod och tilràcklig utfodring af hö och foder-väster gifver altid bättre güdsel-hög, än halm och knapp utfodring af smâ och magra kreatur. Myc. ken och bördig äng ăr i detta afseendet ovärslerlig och förtjänar då namn af Åkrens moder.

Denna matjord täcker Jordklotets yta öfver alt, likväl till olika mägtighet, Alla växter som fornyas hvarje Vảhr, förvandlas till jord, antingen helt och hảllit, eller till en màngd af dess delar. Desse igenom forruttnelsen bringa. de till en ovart Mylla, som med tivarje âr okas, bereder jorden för efretkommande och gifver foda, i början ât smärre, med tiden àt större $V_{a ̈ x t}$ arter. På detta sâtt hafva flere Ö. ar, som utaf Vulkanisk eld framkommit aldeles ofruktbare, med tiden blifvit beväkte och befolkade. Den magraste jordlapp i Sverige frambringar ofta endast Fráken [Pteris aqvilina]. 


\section{)$\quad 7 \quad 6$}

Denna yfviga växt, som sjelf behofver ganska lilet füde äm: ne, gifver genom förruttning en ymnig portion matjord, hvaruti inom nägre àr, Björkar och andre Lüfträn frodas.

Matjorden kan och bör sâledes anses för det hufvudsakligaste födo-ämne, som för hvarje lefvande växt, i mer eller mindre myckenhet fordras, uplöst uti vatten, och med vatten förenadt. Efier denna inatjords mägtighet upskattas jordens bôrdighet, och efter dess myckenhet bedìmes frukıbarheten af den jord, som skall odlas. Då den sâledes ingảr i förening med växterne, m̊sste den naturligtvis mer och mer förminskas, och efter längre eller kortare tid förnyas. Ju flere skördar tagas af en viss jord-rymd, ju mera säges den utmärglas, och behöfver oftare omgödas, ju oftare den besås. En 'Trädgârd, som ârligen besâs, mâste derföre ârligen gö, das, orn den skall löna Odlarens möda.

En vảl gödd Åker äger större förmåga, äfven att skynd. sammare drifva växten till ansenligare höjd, och starkare grönska, samt of ta talrikare rotskott. S d och gräs visa sig på en sådan jord, tätare, bredbladigare, högre och frodigare; dả samma slag af väster, pả en mager jordlapp, stả glesare, spinsligare, lảgare, enklare och blekare, med små oansenliga frön. - Pả en sädes.åker der renarne blifvit mullplogade ocb Matjorlen till en del bortförd, finner hvarje Landtman sin Rảg tưnn, kort, med smả ax och fina korn, $\mathrm{i}$ jernförelse med det, som midten af âkren frambringar; samt vitt korn ännu ümkligare, eller aldeles utträngdt af Landthafran. - De fồrsök, som blifvit anstälde med Sibiriska Ärtbusken, [Robinia], haf; 


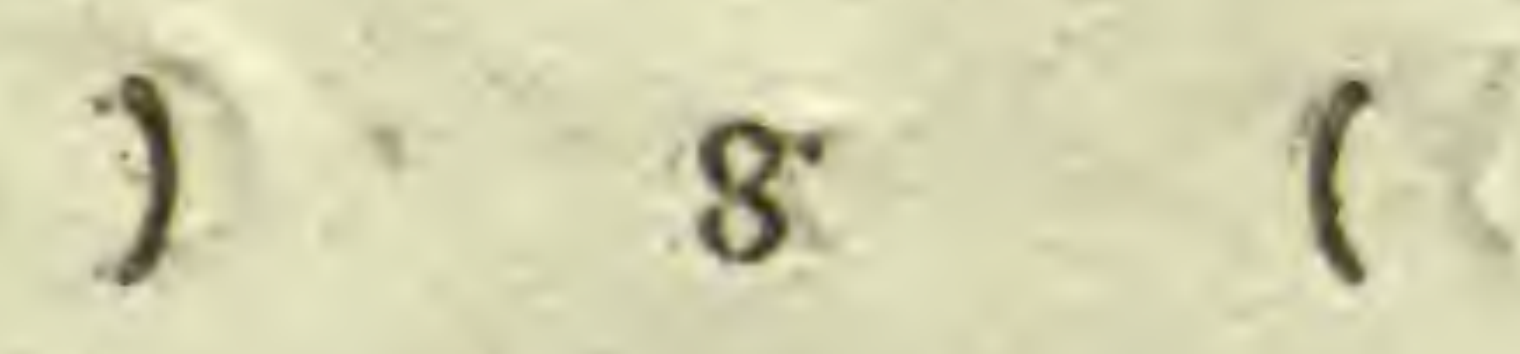

va bestyrkt denna sanning. - De buskar, som blifvit plan: terade uti ett upkastadt dike, som fyldes med brunnen matjord, växte frodigt med vackraste grönska, med mảnge skott och tidig blomning; De âter som nedsattes uti vanlig jord, utan godning och vatnades for öfrigt lika med de förra, tycktes snarare vela dö ut, än vära, och sảgos, eländige med flere torkade grenar, samt blekgula snart wisnande blader. - Et vanligt Lof́cràd, planteradti god jord hat kunnat skjuta bela sex qvarter, pâ en sommar, dâ ett annat, salt i mager jord, knapt kunuat lifnära sig, fatta stând-punkt och vaxa mycket lảngsamt, Hvar och en god husbållare känner denna omständighet, - Pả en mager åker utsår han tátare sin säd, nch ett Tunneland fetare ảker gifver han minclre utsäle: Ä́ven. som han altid väntar sig yınnigare skörd af en väl gjodd åker, än af en mager. En mager åker kan väl năgon gång, under sả kallade Regnår , gifva ymnig växt: men en fetare âker gifver då, af samma orsak, ännu ymnigare säd, så framt icke regn faller till den myckenhet, att den frodigare vär. ten quáfves af för mycken näring, likasom ett djur af sin egen fetma.

6. 3 .

Vatn är det andra hufvudsakliga födande ämne, sam hvarje växt oumgängeligen behüver, för att kunna lefva, ¿illväxa och förükas. Utan vattn kan intet annat födoämne uphämtas af någon ört. Födoämnet må vara hvilket som hälst, \&å mâste det vara i vattn så uplöst, att det af de finaste rör kan indragas och till alla Ytändar framtränga. 


\section{) 96}

Somlige växter, $i$ synnerhet de, som tillhöra de corraste ö. demarker, kunna ganska länge uthärda uan valtn; men längden förgảs och dö âfven de, utaf tảngvarig torka. De màsta örter tillväxa skyndsamt och utbreda sig ymnigt, då do tillräckeligen vattnas. Trägårdsmästarens hela konst hvilar pâ denna Pelare, sedan jorden $\mathrm{i}$ ôfrigt blifvit väl be. redd, När lângvarig torka infaller, om jorden än är aldrig , så väl häfdad och gjödd, sầ spår sig landtmannen antingen fin och ringa gröda, eller ocksà missvaxt. Han suckar derföre efter regi, och när det $\mathbf{i}$ tillbörlig ymnighet, samt $\mathrm{i}$ rättan tid intrăffar, lofvar han sig en rikare gröda, och glüder sig ât den tillkommande skörden. Somlige örtsłag, sâsom den saftulle Spinaten och den genomskinlige Balsami, nen, består af nästan intet annat, àn vattn. Dess jordagtiga delar äro ganska ringa. Andre âter äga ett motsatc fợhảllande och kunna âtnöja sigg med mindre valtn.

Således, ehuru nstridigt det synes vara, alt vattn och matjord ăro basis för det födande ämnet, hvaraf hvarje VäxtRikets varelse utyecklas och underhålles; så torde likvàl vatnet kunna anses, som det förnämsta och nödvändigaste der. af. De rön, som i detta afseende blifvit anstâlde, hafva. bestyrkt denna sanning. Helmonts försòk är ganska märkligt. Han $\log 200$. H. Jord, väl torkad i ugn. Denna lades i ett Käril, som täcktes väl med ett jernbläck, försedt med fina hả. Uti Kärilet planterades en Pil-quist af 5. \#. vigt. Efter 5 års förlopp vägde Pil trädet 169 \#. och 3 unts, oberäknade alla affallne Blader. När jorden sedan văgdes, funnos knapt 3 unts deraf förlorade, sả att 2 f regn-vatín. 


\section{) 10}

hade Trädet vunnit nästan hela sin tilloäxt. Igenom ymnig vatning frambringas årligen uti Trädgårdarne en myckenhet $S$ pinat och andre ätbare Köksväxter, áfven som af en svag och eländig ranka tillväxa, inom fả veckor, stora ochy runga Melones och Arbuser. Igenom ymnig vatning ur. breda sig Trüden icke allenast uti flera och störe blad och grenar; utan sjelfve blomknopparne, für kommande året, tilldanas deraf uti störe mängd. Eu dylikt Exempel har H:r Pıæses haft tillfälle att se hos den kunnige Trägårdsmastaren Ackerman, hvilken en sommar företog sig, att ovanligt ymnigt vatna sine Pomerantgträn, hvaraf foljolen visade sig det påföljande âret, dả Ḷan erhöll en ovanlig myckerıhet Pornerantser. Den ovärderliga vinst, som vatnet sâlunda, så. som det nödvändigaste fodoämne för växterne, tillskyndar en idog Odlare, har lärt den omtänḱsamme Chinesen, att leda: genom sido-Kanaler, det frản bergen nedrinnande flodvatner, rill sine Trägårdar nch åkerfällt, för att under den torra âstidien vatna dem och vinna en högre afkastning. Brist på regn kan ej ersättas genom nảgon slags godning, ehuru, en val gjödd åker kan mera fortskynda sả väl en allmännare fröns groning, som deras hastigare tillväxt, och äfven bättre motstå en lảngvarig pâfóljande torka. En omtänksam åkerman utsår derföre orn vảsen, sả snart âkren băr hästen, sitt korn och nedharfvar det Af den must jorden dä äger, kommer kornet gerna allmänt till mältning, då det sednare utsâtt, gror dels ganska ojemt, dels med svagare brodd upkommit, af infallande torka fürvisnar. Nảgre dagar efier ett sådant tidigare utsáde, dả åkren reder sig kan han mẹd Trädb stucken nedköra sitt redan grodda korn, och nedliarfva det, 


\section{) $11 \quad($}

då andre först börja sitt utsäde, hvilket, om lảngvarig torkæ påfoljer, blifver antingen ogrodt eller smả.växt. Vattn är altsâ af högsía vigt, och det nòdvändigaste af alt fór hvarje Iandtman, det sakrasie medel lilt jordens frugtbarhet, det ymnigaste af alla Elementer på vår jord, det cumbarligaste for Djur och vaxter, for alt, hvad lif äger. Utan Nilens välgörande ofversvämning skulle, Egyptens fält, lika med närgränsande Öknar, stả aldeles öde. - Största delen af A. frikas vidsträckta ödemarker stả, i brist pá regn, floder och insjöar, aldeles nakne, skoglöse, förbrände, ofta otillgänglige och obebodde af djur och Människor. - Hvarenda Bonde i Sverige vet ganska väl, dâ långvarig torka om sormmaren infaller, att sädeshalmen blir fín, och sädeskornen små; äfvensom Trägấrdsmästaren ser Spinaten och andre Grönsaker, med smâ och snart torkande blader fortskynda till sin blomma och frösättning.

Vattnet är sâleđes för Văxt rikets behof och näring af yttersta vigt. Det utgör den tunna vätska, som förmâr intränga neh upstiga i vätskornas rör; som skall uplijsa och föra med sig alla andra närande delar; och som äfven skall förena andre, för vảxtens underhâll nödige, men ej utam detsammas âıgärd, förenliģe ämnen. Urom elden, är vat. net det màst lósande ámne, som genomtränger, snart sagt, alt, och till växtens alla delar medforer alt det, som kan tgana till dess utveckling, underhâll, tillväxt och vidare forto plantning. 


\section{THESES.}

\section{I.}

Quemadmodum studium Historiæ Naturalis in genere hominem ad pleniorem Supremi Numnis ejusque Perfecrionum notitiam perducit, sic oeconomiam Plantarum scrusaturo, in primis Summi Creatoris Magnalia patebunt.

\section{II.}

Nemo hon novit, Animalia absque alimento vivere non posse; at Vegerabilibus suum quoque esse æque necessarium, scire juvat.

\section{III.}

Admirandum sane Naturæ mysterium, quod unicum hoc nutrimentum tam diversa efficiat, non in diversis modo Plantarum speciebus, sed eriam in una eademque Planta.

\section{IV.}

Multum Agriculturæ consuleretur, si lætamini artificiali parando, major impenderetur cura.

\section{V.}

Sed in Agriculcura si proficietur, antecedat necesss est, exacta variorum terræ generum cogaitio. 


\section{DE NUTRITIONE PLANTARUM \\ CUJUS}

PARTEM SECUNDAM

VENIA EXP. FAC. MED. UPSAL.
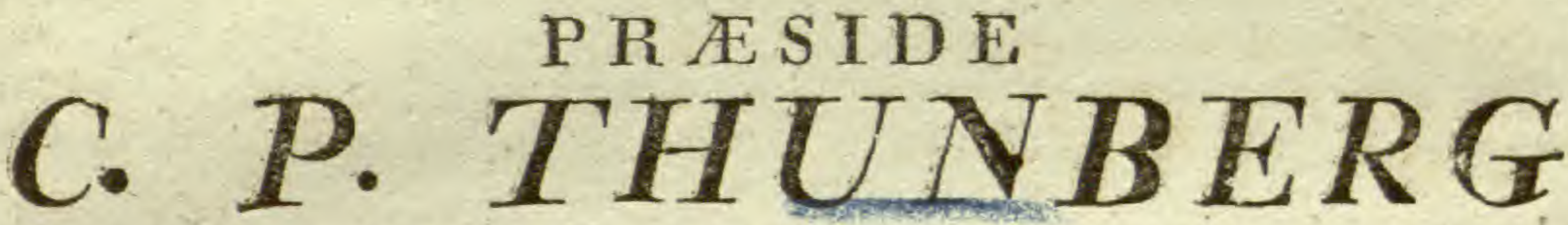

COMMENDATORE REG, ORD. DE WASA,

Med, Doct, Prof, Med, et Rot, Reg. et Ord. Reg. Coll. Sanit. Memb. Hon. Acad, Chesar. Petrofol. ex Nat, Curios, Reg. Scisnt, lond. Holm. Agric. Med. et Evang. Societ. Oecon. upsal. Patr. Hoim, gt Civ. Oecon. Fini. Honor. Wermel. Westm. Calm. ét ỏrebr. Berol. Nat. Scrut. Paris. Hafn. Moscou. et Halens. Hist. Nat. Goren K. Puil ad, Lund, Harlem. Amstezd. Oecon. et Inst. Litt. Zeland. Nimisiens. turicens. Ifnens. Linn. Londin. Reg. Scient. Phys. et Phytograpi. Góttingens, Scient. Gothob. Munach, Erlang. Wetter. Nanciens. Marpurg. Med. Paris. Emul. Monspel. Med, Matritens. Med. et Nat. Studios, Enimb irg. ex Petrop. Medico Chir. Membro nec non Acad, Scient. Paris. et Institut. Nation. Monspbliens. Agrieult. Paris. Medic. Londin. Sicandinav. Florentrin. et Batavin, Ind, Or.

CORRESTOND,

P. P.

\section{AND. BERNH. LINDROTH STIPEND. REG. SMOLANDUS.}

IN AUDITOR, BOTANICO D. IX. JUNII MDCCCXIX.

3. A. M. S.

Mo. Bot. Garden.

1896.

U P S A L I $\mathbb{E}$

EXCUDERANT NEGIR ACADEMIA TYPOGRAPAI. 


\section{GUILLEMETTE MAR. LINDROTH née de GRA A N ER,}

\section{Ma très chere Tante!}

La vraie reconnoissance demande en vain une expression du sentiment de l'ame; car sa perfection depend du coeur, dont les nuances delicates rarement nous peint l'image exterieur! Et quels hommages pourront nous payer à la bonté consolante d'une bienfaitrice, si la verlu, quand meme placée loin de nous par la nature, jamais elle n'eut influé sur notre bonheur, a droit de pretendre à nos sacrifices. Et ne faut jl pas aussi qu'un seule sentiment deponille ainsi la mecanisme de la parole; car ce n'est qu'à travers l'etendùe immense de la pensée, que l'infini se presente aux sollicitations des mortels. Mais il n'est pas pourtant une inquietude doulonreuse, qui rend ce vif desir plus difficile, c'est un plaisir inexprimable de l'ame, que de confondre les objets, qui l'interessent dans la vie avec les vives attentes de l'esperance, dont le bonhenr paisible et doux, s'annonce par l'harmonie interieure, où les passions humaines ne doivent penetrer, et qui nous laisse gouter d'avance la felicité de la vertu. Dès les premiers jours de ma jeunesse, je promis d'honorer les noms sacrés de la vertu et du bonheur! Cest l'hommage à l'une, qui ne me fera pas indigne de l'autre! Et peut-être rien n'excitera plus vivement cet interet, que les rapports, dont nous laisse jouir un esprit cultivé par les scienees et les belles lettres; car l'esprit c'est lá vie eternelle de la raison, qui eleve les mortels au dessus des malheurs et des souffrances terrestres et nous fait vraiment sensibles et bons; et quoique jeune encore, je n'ai rien gouté de cette exaltation coeleste, que dome la profonde etude de la nature, je vois pourlant cette combinaison interieure, qui est le fondement de la religion et de la morale, et qui me ramenera toujours de ce monde physique à la contemplation de ce qu'il y a plns haut et plus saint. Permettez moi, donc, Madame, de vous offrir les premiers fruits de mon travail, votre nom sera toujours la gloire de mes succés, et votre felicitè l'objet de mes priers, et ne rejettez point ce tribut religieux d'un eoeur pur' et simple, qui n'osera jamais depasser les bornes du respect profond

avec lequel je suis Madame 
FABRIKÓREN

HerR D A N I E L W I B ER R samt dess Fru

ULR I Q U E W I B F R G född HOFFMAN

ENKEFRU FABRIKOீRSKAN

A NNA CATH. BLOM M NDAHL född HOFFMAN

RÅDMANNEN OCH FANDELSMANNEN

Her $\mathrm{N}$ I L S L U N D G R E N

samt dess Fru

CHRIST. CATH. LUNDGREN född WIBERG

Huldaste Anförvandter!

Emottagen med välbehag detta vördnadens och tacksamhetens heliga offer

af

Eder

idmjukaste tjenare BERNDT LINDROTF. 


\section{F Ö D $O-\ddot{A} M N E N$.}

\section{5 .}

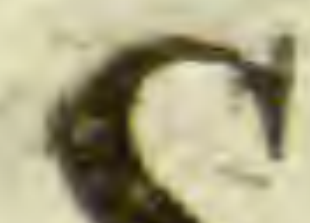

Walter, Alkalier, Syror, så väl faste, som flygtige, ầro alt. mänt erkände, såsom starkt drifvande och växten befordrande, innom växtrikets område. Deras fina, af vatn upplösta delar, kunna ingâ i växternas trânga karaler. Eıt träd, som planteras uti en grop, uti hvilken en död hund blifvit nedmyllad, tros allmänt af djurets förrutnande och dess utvecklade ångor, vinna en starkare tillväxt. Den säd, som stöpes uti Saltpeter, både gror och växer frodigare, än cn annan ostöpt. Efter svedjande fär man siundom se en $\mathbf{y m}$. nig växt, och ej sällan flere stånd uppskjutne frản ett enda Râgkorn, äfvensom aken blifva af ovanlig längd. Tran. grums anses $i$ Bohus Län, sásom ett ypperligt gödnings. ämne, för sin olja och sitt flygtiga Salt, Urin-samlingar med gödsel tjäna äfven för samma orsak. Detta allt har vållat, att man tillägnat Salter en stark utvecklings - förmåga, och anset dem såsom tjänlige födo-ämnen för alla växter. Att salter ingå uti Växterna och utgöra deras bestảndsdelar, fin. 


\section{)$\quad 14 \quad C$}

ner man lätt af den salta smak, som sjö-växter vid hafs strän: derna, och succulente Växter uti Africas och Siberiens ödemarker äga, såsom Salicorniæ, Salsolæ, Crassulæ, Mesembryanthema och mångfaldige andre, livilka till aska förbrände gifva Soda salt. Ehuru man icke lärer kunna frânkänna Salterne all egenskap af födande ämne, är det dock sannolikare, att de snarare böra anses, som retande medel, att sätta växternas fibrer och rör uti starkare verksamhet, at insupa bâde vatn och de $i$ vatnet uplöste födande ämnen af mat-jorden. Jorden mattas ògonskentigen af dem, sã att svedie-land, efter en eller tvänne skördar, för längre tid blifvez ofrugtbart. Ymnigt använde göra de mer skada, än nytta, och böra derfüre med försiktighet och måtta användas. Otvifvelagtigt bidraga Salter dertill, att de oljagtiga delar uti matjorden kunna förenas med vatnet, och att den deraf sâledes tilltredda Sâp lut kan lättare ingả och uppdragas af växt.rören, samt gifva ett födande ämne, som verkar med större styrka, än den, som vatnet ensamt skulle kunna åstadkomma, Aska efter förbränd ved och äfven Sot, räknas till godkände gödningsämnen. för det Lut salt, och den fetma, som. de innehålla,

8. §.

I likhet med Djuren, tarfva Växterne till sin tillväxt och trefriad, icke blott föda, utan àfven tjänlig Luft, Ljus och Vårme, hvilke alle äro oumgängelige sâ väl för det ani- 


\section{)$\quad 15($}

maliska, som det vegetabiliska lifvet. En växt vantrifves alltid uit en instängd, oren luft. Uti en mörk kăllare blir växten blek, sjuklig och vanstäld. Utan en viss grad af värme, som likväl är olika för olika växter, kan intet frö gro och ingen ört fortkomma, man må vatna och göda den så mycket man behagar. Utaf Solens ljus och värme upfri. skas allt lefvande i hela Naturen: Hvarje växt lifvas deraf: fröet öfvergår till groning: saften upstiger $i$ de uividgade rören: knopparne på träden förstoras, öpnas och utvecklas: blad och blommor framalstras: frugten vinner sin mognad och hela växten hinner sin bestämmelse, enligt den allgode Skaparens allvisa afsigt. Sol-rosen vänder sig hela dagen efter Solens framskridande ifrân Öster till vàster. Alle de blomster:växter, som stállas vid fönstret, böja sig lutande ât sol-sidan, förde af Solens dragnings.kraft. Ställes en Tulpan i fönstret emot Solen, så utbreda sig blommans blader nästan horizontelt, och om hon straxt derpå ställes i skuggan, sã drager sig blomman tillsammans. Af Solens välgörande ljus erhålla alla växter sine liflige färgor. Under dagens Sol-sken och uti fri luft insupa bladen oxygen, dâ de deremot om natten samla uti sig kol-syran. Denna attraction omväxlar beständigt och torde, fastän i ringa mohn, bidraga till växtens underhâll, äfvensom växterna af nàtternes fugtiga dagg underhâllas och upfriskas ef er dagens mattande hetra. Köld äger, emot värme, en stridig verkan. Den skallar och hindrat all vegetation. Ju lögre växterne finnas på berg i en kal. 


\section{)$\quad 1.6 \mathrm{C}$}

lare lufikrets, desto mindre och lägre äro de till alla sind delar. Af en viss grad kôlu kunna alla växter dödas. De hetare klimaters ómtâligare alster förlraga icke de kallare länd rs strängare kyla. Nür vintren uri vår Norll annalkas, blekna och falla trädens blader, och hela Floras blomsterarmé bereler sig, att gả uti vinterquarter. När vinterköldon om vảren länge fortvarar, framkomma vâr. växterne sent oclı Trädlen öpna dả äfven hela mânaten sednare, än vanligt, sina blommor och löfknoppar. Varme är sålunda för hvarje lefvande växt a, högsta nödvändighet, äfvensom Solens ljus och Lifs lufien. Desse vederiqvicka och uplifva allt, same tillika med regn och den dyrbara matjorden frambringa pa ytan af vârt jord klotall den heundransvärda pragt, som med hvarje år förnyas till Människors ocl Milliarder andre va. $r \in$ l'sers nytla och glädje.

\section{9. §.}

Uii första delen är visat, att Leran ren ocls utan tîfr. blandning af matjord, icke närer nágra växter; sanden ren icke eller och näppeligen kalken, i och för sig sjelf, Mat. jorden deremot, blandad med lera, sand, kalk ocli andre ämnen, uti olika proportioner, är tillika med vatn, väx₹ernes förnämsta födo-ämne. Ju tunnare Matjorden befinnes, desto tnagrare aker: ju djupare och ymnigare, desto fetare cch bürdigare. Att òka dennas myckenhet, bör derföre va- 


\section{)$\quad 7$}

ra hvarje god hushâllares bemödande. Vatnet är äfven lingst nödvändigt för hvarje vảxt-rikets alster. Det förutan crânar oeh boridör allt, jorden mả bestâ af hvad ämnen, bom hälst. Nödig vataing för sin odlade jord kan en Iandtman aldrig, eller sällan i stort anskaffa. Sãdant besor af jordmonens egna läge, af regn, himmels-strek, årstider, åskvàder, öfversvämningar eller andre tillfälige orsaker. Hans förnämsła omsorg bör derföre rigtas derhän, att utsả sin säd pã tjänlig tid och àga en sådan jord•blandining, son längst bibehåller nödig fuktighet. Man har chemiee undersòkt jord arterne och stora formoner hafva blifvit utlofvade af deras användande till sảdane jordblandningar; men desse hafva oftast blifvit kostsamme, sâ att de af Landtbonden i allmänhet icke kunnat begagnas, utan blott fallit pâ en idog Trägârdsmästares eller förmógen Stånds-persons lott. Der landet uti China och Japan är kulligt, leda desse tvänne idoge jordens odlare, det ifrản bergen ström-vis nedlöpande vatnet, zenom grăfne sidokanaler, till sine àkrar och planteringar; och på Goda Hoppsudden utofvar äfven den flitige Nybyggaren samma konst, för att vatna sine Vin-land och frugtträgârdar. Utom dess nytija de tvänne forra Nationerne et vatnings- och gödningssätt, som andre sällan eller aldrig begagna, nemligen: sedan de samlat med omsorg all den spill. ning, som faller efter djuren, tillika med urin och afskräden från hushållet, omröra de detta med vatn till en mölja, utbära den uti 2 :ne ämbar och med en slef begjuta den up. 


\section{)$\quad 18 \quad($}

komna kvarterslånga brodden. Sãdant kản verkställas endast uti folkrike länder, der jordbruket äger hela sitt värde och der inge hinder ligga $i$ vägen för Landtmannens idoghet, sâsom öfver allt $\mathbf{i}$ det lärda och uplysta Europa.

\section{§. 10.}

Efter Naturens allmänna Lag trifvas vissa växter väl uti en magrare jord: somlige bättre uti lera, som Gås örten (Potentilla anserina) och Hästhofven (Tussilago farfara): andra bättre uti sand och lous jord, som Spergel (Spergula arvensis) och Qvickroten (Triticum repens): andre âter äska mergel eller kärr.jord; derföre bör altid någon af desse jordarter vara med matjorlen blandad. Likaså är en sidländ och vattenrik jordmon tjänligare för vissa växter, såsom kassevia (Poa aquatica), kafvelgràset (Alopecurus pratensis och fiorin-gräset (Agrostis). Både groning och mognad beror of ta häraf, stundom till flere dagar ock flere veckior. Sảlunda gror till exempel både Rågen och Kornet mycket hastigare uti Sandjord, än uti Lera, samt mognar äfven uti den förra snarare. Dả man sálunda förmärkt, att somlige växter kunna fortkọmmıa pả en naager jord, och att andre derstädes trâna bort eller dö af brist på föda: dâ man tillika selt, att somlige växter kunnat ymnigt förökas pâ en sank jordmon, hvaräst andre vantrifvas och fördränkas: dâ erfarenheten lärt, att en fetare jordmon icke allenast frambragt en ymnigare skord, 


\section{) 196}

wtan siundom genom öfverflödig föda förorsakat sjukdomar och gifvit mera gräs, àn kärna; sả är det af mycken vigt för en hushâllare, alt väl känna, huru, jorden för hvarje särskild odlings-văxt hör vara beskaffad, för att deraf draga mästa nyttan. Erfarenheren har äfven visat, att vissa växter i ymnigare mått fordra fỏdo-ämne, och sảledes mera matta jorden, än andra, och att växterne $i$ allmänhet mycket mer matta jorden, dã de gả i frä och gifva mogen frugt; äfven som, att somlige växter i denna del överıräffa andra, efter deras olika beskaffenhet. Allt detta förtjenar en Landtbruka* res upmärksamhet och gifver honom anledning till alla de nödiga förändringar och anstalter, som vid ett omväxlande. jordbruk kan befordra hans mästa nytta.

\section{II. .}

Dâ de magre jord-arterne lera, sand och kalk icke egenteligen innehâlla något födande ämne för nâgon vảxt, utan tjäna mer till fäste för densamma och sâsom ett ämne, hvarmed matjord, vatn, oljor oth salter kunna blandas och förenas; så kan man icke söka hos desse jordarter någon förminskning eller förändring, som en uppvảxande gröda förorsakar. Mat.jorden åter, eller Svartmyllan innehåller fle. re lätt löslige och fine delar, i synnerhet kol-ämne, olja och salter, hvilka alla lảta upplösa sig uti vatten, det allmän. naste lösnings -ämnet pả vår jord, och igenom förening sig emellan göras tjänlige, att upstiga i växtens fina sug, tör, 


\section{) 201}

för att spridas till alla särskilda delar, och gifva hvar och en den föda och den form, som Skaparen för hvar och en, efier dess särskilda (mechanisme) bygnad bestämt. Denna operation måste krafrigt understödjas utaf den omgifvande luften: af värmen, som genomtränger och utvidgar allt: af Ijuset (Lyset) såsom en stor orsak till (attraction och exhalation) indragning och utdunstning, samt äfven den egna omärkeliga Lifskraft, som blifvit särskild gifven àt hvarje lefvande varelse, som är af mycken och vigtig betydelse och som icke lärer kunna underkastas någon chemisk granskning.

\section{2. \$.}

Hvad, som sâlunda bör komma i betraktaude, är Matjorden med dess beståndsdelar, hvilka undergå en beständig minskning dels af den föda, som en växt deraf drager till sig, dels af alt det, som luft och vatn upplöser och bortdunstar uti ångor. Aldrig klagar någon Landinian deröfver, att leran förminskas på dess ler-àkrar, eller sanden på dess sandiga ảkerskiften. Deremot är den klagan almän, att, matjoirden förminskass att åkren blifver, efter hvart säde, fattigare, icke pâ lera, kalk eller sand, utan pâ mat-jord. Ingen Bonde förer lera på leråkrar, eller sand på sandảkrar, sâsom gödnings.ämne. Gödsel ifrån ladugåaden, torf ifrản backar, dy·jord ifrản kärren, spånor if rản vedbacken, aska, sot och dylikt, med ett ord allt, som kan förvandlas till svartmylla, eller innehâller salt och fetma, utgör hans enda, ste så kallade göd̉inings ämne. 


\section{THESES.}

\section{I.}

Qui attentis oculis librum observat Naturæ, infinite mul. tis constantem foliis ad omnium rerum Greatorem veneran: dum, facile ducitur.

\section{II.}

Omnium rerum, ex quibus aliquid acquiritur, nihil sane est Naturæ cognitione melius, nihil uberius, nibil dulcius, nihil denique homine libero dignius.

\section{III.}

Cognitionem Herbarum in omni vita genere prodesse nemo in dubium vocabit.

\section{IV.}

Magni sane interest, inde a teneris annis etiam ad mi: bimas res adsuescere oculos advertere attentos.

\section{V.}

Iis, qui rei rusticz incumbunt, cognitio morborum, guibus arbores herbaque sape Iaborant, est utilis.

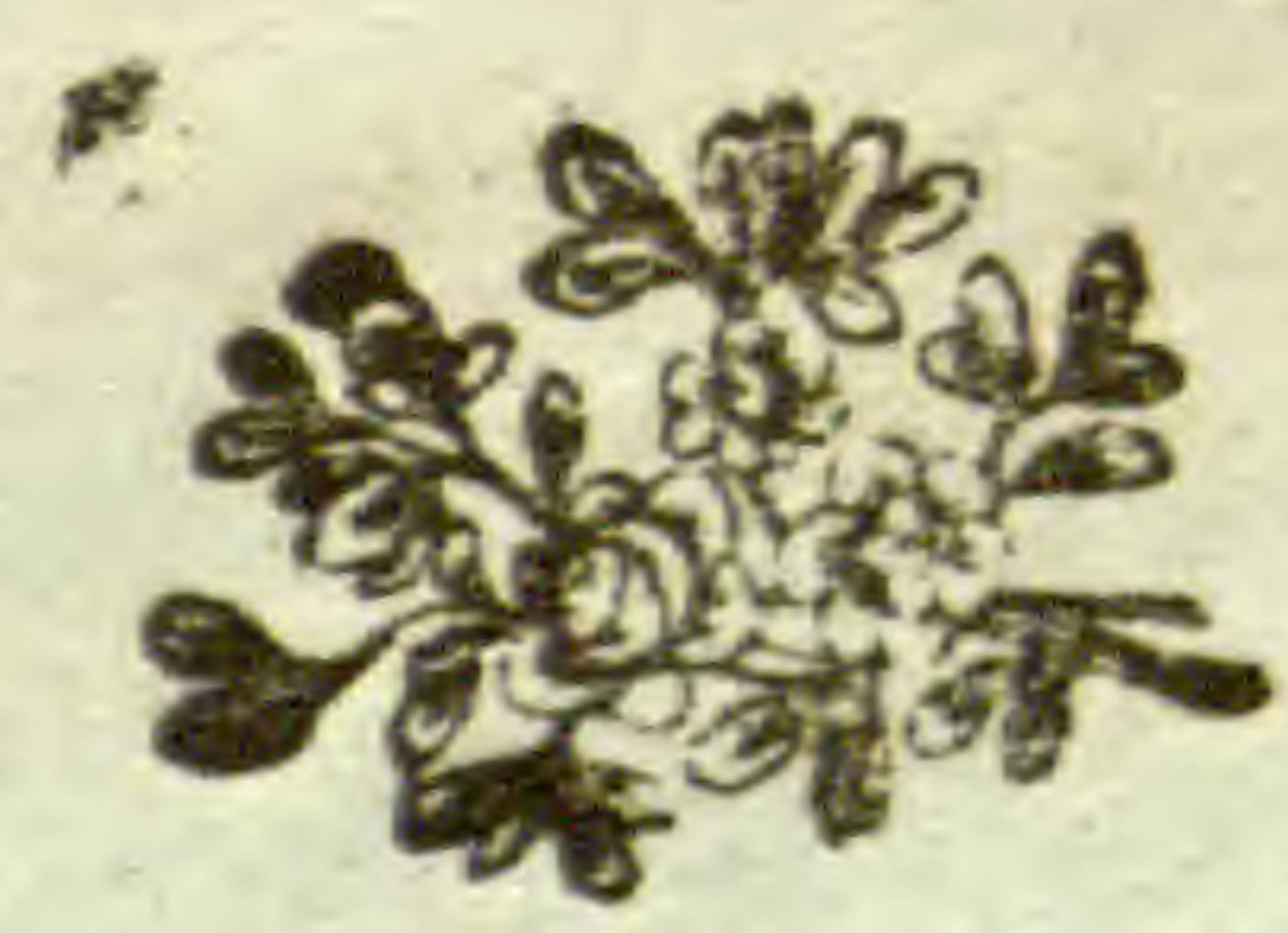




\section{E \\ NUTRITIONE PLANTARUM \\ CUJUS}

PARTEM TERTIAM

VENIA EXP. FAC. MED. UPSAL.

PRASIDE
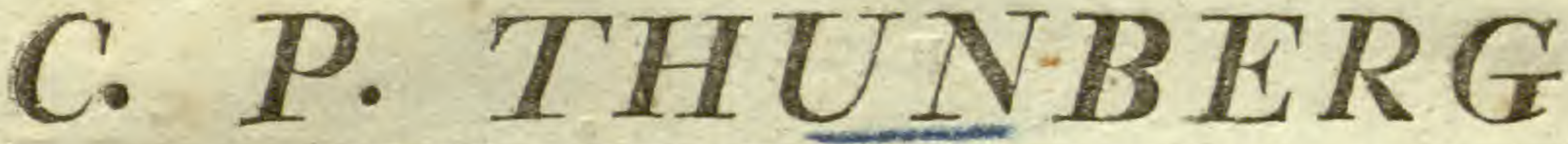

COMMENDATORE REG, ORD. DE WASA,

Med. Doct. Prof. Med. et Bot. Reg. et Ord. Reg. Colz. Sanit. Memb. Hon. Acad, Cesar. Petropnl. ex Nat. Curios, Reg, Scisnt. Lond, Holm. Agric. Med. et Evang. Societ, Oecon. upsal. Patr, Hotm. et Civ. Orcon. Finl. Honor. Wermel. Westm. Calm. et órebr. Berol. Nat. Scrut, Paris. Hafn. Moscou. et Harens. Hist. Nat, Gorenk. Puilad, Lunt, Harlem, Amsteld. Oecon, et Inst. Litt, Zeland, Nidrosiens turicens, InNens. Linn. Londin. et horticutur. Reg. Scient. Phys, et Phytograpl, Góttingens. Scient, Gothob. Monach. Er la ng. Wetter. Nanciens. Marpurg. Med. Parts. Emul. Monspel. Med. Matritens. Med, et Nat. Studios, Emimburg, et Peitrop. Medico Chir.et pharmac. Membro nec non Acad. Scignt. Paris. ext Institut. Nation. Monspeliens. Agricuit. Paris. Medic. Londin. Scandinav. Florentin, et Batavin, Ind, Or. Correstond.

P. P.

\section{ADAMUS HEDRÉN.}

VERMELANDUS.

IN AUDITOR, BOTANICO D. IX DECEMBR. MDCCCXIX.

H. A. M. S.

Mo. Bot. Garden,

\section{U P S A L I $\mathbb{E}$}

EXCUDEBANT REGIA ACADEMIR TXPOGRAPHT. 


\title{
XRYDDKRA MHANDLAREN
}

H O̊ G Å D L E

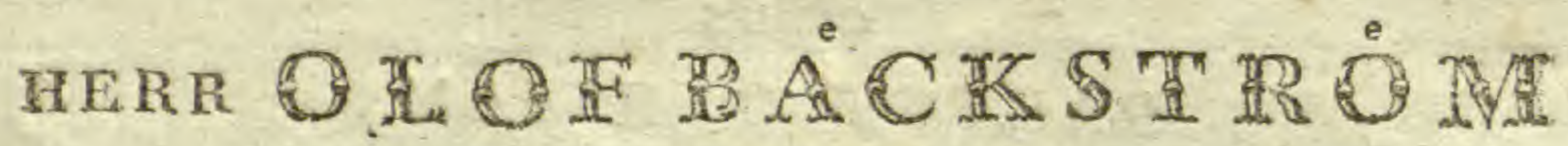

SA M T

H O̊ G Å D L A

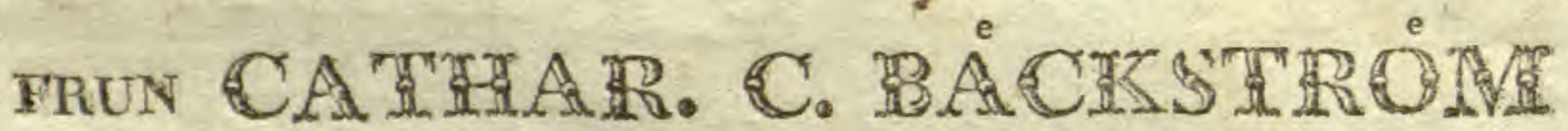
FöDD I M M R M A N.

\author{
Vödnadsfult och tacksamt
}

eff

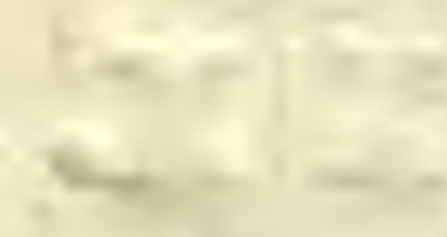






ADAK HUDEÉN. 


\section{THESES}

I.

Liber Naluı omnibus ad legendum patet, foliis suis infinite multis, sapientiam et omnipotentiam Creatoris luculentissime manifestat, omnes-que ad Denm venerandum, quain maxime ducit.

\section{II}

Regna Naturæ intimo inter se cohærent vinculo, limi. tesque eorum non certe definiri possunt.

\section{III}

Herbarum cognitio, ut semper est jucunda et dulcis, ita et omnibus temporibus utilis.

$$
\text { IV. }
$$

Si Botanica tanti est pretii, de quo nemo dubitare possit, agriculturæ haud est aspernanda.

\section{V.}

Agriculturæ studiosos Chemia multum juvat, si terram cuilibet seminationi aptam, fructuumque fecundam, velint. 


\section{O M}

\section{W $\ddot{A} X T E R N A S$}

F Ö DO-ÄMNEN.

13. $\$$,

A tt denna gödsel gifver bättre gröda, derom är bonden försäkrad, äfven som, att åkren blir i samma förhâllande mag. rare, ju flera grödor hämtas af densamma. En åker, som tvingas utan gödning till flere ârs grödor, blir sluteligen sả utmärglad, att han icke bär nảgon slags gröda, åt. minstone icke lönande. Om Râg sảs pả nygödd âker, så blifver första grödan derefter den bästa och ymnigaste: andra gröo. dan mindre både till myckenhet och halt, emedan gödningens mängd och kraft redan blifvit förminskad. Tredje och föl. jande ârens afkastningar blifva sämre, och gifvande alt mindre och mindre. Lägges en sådan nygödd ảker $\mathrm{i}$ träde och fảr hvila hvart annat år, sâ hämtar han under denna hvilotid tilbaka i nảgon mohn nảgot tjänligt närings-ämne, dels utur luften, dels af det ogräs, som upväxer, nedköres och formultnar, dels af den spilning, som faller efter kreaturen, som afbeta trädes-jorden. Detta visar nogsamt, att gödselens födande delar af hvart säde förminskas, och att de samma måste blifva ringare för hvarje påföljande säde, samt jorden $\mathrm{i}$ samma förhâllande magras och afmattas. Att afhjelpa denna 
olägenhet, veta kunnige Hushalllare, att besâ trädes-jorilen med Bohvete, som till gödnings vinnande nedköres, eller med Vicker, hvaraf stommen, sedan örten grön blifvit afslagen, nedköres, för att rutna och göda. Den stomm, som blifver efter de vanliga bärgade och i frö fullmognade sädesarterne, är aldeles förtoıkad och gifver altsâ nedkörd ett ringa förrâd af närande Växijord.

Den föda, som en Väst niuter af matjorden, kan dock ejensam vâlla all den öfverklagade förminskningen. Mycket diznstar bort och förflyger i lufien, i synnerhet dess oljagti. ga delar och flygtiga salter. Vatnet, som skulle förvandlas iill Vảxternas bestândsdelar, nedriuner, till någon del, dels i jorden, dels uti större mängd förflyger det i lufien, för vandladt till de finaste ångor.

\section{4. $\$$.}

Ingen Taandtman tviflar derpả, att jorden mattas af flere förnyade säden; men hvarföre deti malias mera och matjorien sảledes mera fourminskas, đâ en Växt fàr gå till mngnad, âr en annan omständighet, som ãfven bör komma $\mathrm{i}$ betraktande. Uion den allmänna sanning, att ju mera frảntages, dả en Växt längre tid fâr växa, desto mindre mãste blifva öfrigt; så torde granskningen af en Växts bestảndsdelar uti blad, stjelk och grenar, jämfürde med bestảndsdelarne utaf blomman och frukten kunna leda till denna uptäckt. Desse bestândsdelar đro ganska olika. Stjelken synes danad, för att föra närings. saften till de öfre delar, dá bladen deremot merendels, så. 


\section{) $23 \quad($}

som för vädret rörlige, ersätta den brist, som hos hvarje Växt befinnes, att icke kunna röra sig ifrân sin stând punkr. Desse delar bestå mäst af vain agtige safter, dâ deremot frug: ten och fröet innehâlla ett ymnigt mjöl agtigt ämne, eller Stärkkelse, såcker-ämne, med mera. Uti ett helt ax mângkornigt hvete och uti en enda ärt.skida är detta icke obetydeligt till sin mängd, nch torde mera tildanas af fin mat-jord, än af vatn. Sådane växter, som olmänt är bekant, matta derföre jorden mycket mera, fastän olika, efter sin olika finhet nch frons storlek, Ärter mäst, dernäst Hvete, sedan Råg, Knrn och $\mathrm{H}_{3}$ fra. Att andra starkare och tillika förökade Födo-ämnen mảste tilldana frugtens och fröns kraftigare bestảndsdelar, visar Rotens förhảllande pả många växter, i synnerhet de två-årige (biennes) sâsom pâ Morötter, Palsternackor , Kâlröt. ter, Rofvor och flere. Första ảret äro dessas rötter och blad aldramäst köttagtige och safffulle: andra året utvàxa de uti tunnare, smalare blad och lảnga blomspiror sả häfligt, att all den saft, som roten förut ägde, försvinner, och att roten ănda till yıtre skalet blifver ihălig och fulkomligt tom. Pà fler âriga växter (perennes) försvagas altid, under blomning och frösättning, kraften i roten till den grad, att den sam. ma icke fâr $i$ det tillståndet upptagas till bruk, sâsom ett Medicament, emedan dess kraft àr antingen försvagad eller aldeles fürsvunnen och upstigen uti den öfriga växtens mâng. faldiga utgreningar, blommor och fröskidor. Ett fruģt träd, som nâgon gång bär ymnig frugt, mattas sâ deraf atı det sedan ett eller flere ảr behöfver hvila, för att samla nya krafter. 


\section{)$\quad 24 \quad($}

Ju längre en odlad Växt blir quarstảende pả marken, desto längre ach destomera, under sin tillväxt, behófver den foda af den jord, i hvilken den odlas. En säđes-àkers period ifrân broddens upkomst, till dess sälen skjuter $\mathrm{i}$ ax, är knapt mer, to hàlfien af den tid, som fordras för dess fulla mognad, till hvilken Vaxıen sâledes, under dubbeht längre tid, fordrar dubbelt så mycket fodo ämne, och sannolikt mera, ả dubbelt,

\section{$15-\$$.}

Blommans delar äro mânga, stundom mera tal-rika, än del. arne på hela den öfriga vàten, och dessa, som prunka med en skönare glans, behöfva säkerligen både mera ymnigt och af kraftigare halt fodoämnen, för Honungs saftens tillredning, Hannarnes frö.mjöl och ännu mera för frugtens tillváxt och fröens hehöriga styrka. Sijelkar och grenar synas i almänhet behöf va mycket litet till sitt underbâlt, dả deremot uti fröet concentreras hela styrkan för en tillkommande Generation. Ett sädes.ax är altid tjockare och tungare, än nảgon annan del, och en gren, full af äplen behöfver understöljas. En enda Tulpan.blomma är stor, i proportion emot dess öfriga delar. Gurkor, Meloner och Arbuser äro emot sina nedliggande sva. ge stjelkar ofantligt stora frugter. Elt frugt-tràd, som i luften utbreder sin krona, sảsom en hel trägảrd, belastadt med oräkneliga blommor och tal.rik frugt, fordrar utan all tvifvel en stürre skatt ifrån moder-jorden, än ett löf-träd, medmin. dre och enklare frön. Ett träd, som ymnigt blommar, fram. 


\section{)$\quad 25 \quad($}

visar likasom en ny skapelse, hvilken har bebof af elt ymnigare och kraftigare födo-ämne, understödt af värme och andra bidragande medel, att fullkomna sine frugter och tillreda frön för nya varelset.

Att uti en fetare och oftare vatnad jord mohn det födande ämnet $i$ större ymnighet begagnas af en växt, kan man tydligen finna af näsian alla odlade växter, som fà en ymnìgare gödning, sorgfälligare ans och rikeligare föda. Sâledes ser man stundom den En-blommiga Tulpanen fördela sin stjelk och prydas med flera blommor: den väl-luktande Neglikan förvandlas till dubbel med flera blomans delar utväxta till talrikare blomblad. Uti ảtskillige arter förökas, och ofta fördubblas Stảndarnes (Stamina) antal, De välsmakelige Smultronen, som pả de magrare lerbackar växa små till alla sina delar och gifva smärre bär, frambära odlade i trägården mâng. duhbelt större Jord-gubbar, af âtskillig både färg och skapnad. Alla dubla blomster och alla vanskapliga blomor hafva altså sin tillkomst af öfverflödig föda, och öfvertyga oss om en starkare dragnings kraft till de öfre växtens delar, dả den samma blomar och mognar sin frugt. Härtill medverka lik. väl äfven andre krafter, såsom Luft, Lyse och Värme, ty uti tillslutne rum och Orangerier kunna sällan någre frön bringas till mognad så fullkomligt, som uti den fria luften.

$$
\text { 36. §. }
$$

Härvid måste komma i betraktande ännu 2 :ne andra om. ständigheter, som säkerligen äga en betydande inflytelse på 


\section{) $26 \quad($}

ltvar och én Växt, och göra, att den fordrar bättre ocls ymnigare föda under mognandet af frugten och fröredningen, hvarigenom den jord mera mattas, utur hvilken födoätnuena dragas, än under nâgot annat tillstând af det vegetabiliska lifvet.

Desse äro först i likhet med insțincten hos Djureri, en stark benägenhet eller drif braft hos Växterna, ett ouphorligt sträf. vande, att komma till blomma, och att igenom frön föreviga sitt slägtes tillvarelse. Denna är ganska märkbar, tydlig och onekelig hos alla Växter, som för litet vatnas, eller lida utaf torka, och äfven hos alla dem, som antingen af kreatur afbitas, eller utaf människor afbrytas. Alt lefvande sträfvar till detta mảl, att föreviga sin varelse och att uti kommande generationer fortplanta den kraft, som den Alsmägtige Ska. paren nedlagt uti hvarje enskilts förmåga. Man ser, under torra somrar, alla Växter trảna bort, men ändock attid hasta till sin blommas utvekling. Spinatens stjelk och blad blifva dâ odugelige till Mànniskans näring, och Växten liten och klen hastar med skynsam fart till frö.sättning. Om en Vaxt afskäres, dả den visar sine blomknoppar, sả skall man snart finna, att ifrản roten, eller nedra delen af dess stamm be. ständigt frambryła nya blommor, fastän smâ och på kortare stjelkar Sâdane försók kunna lätt anställas med de allmännasto växter, såsom Leijontanden (Leontodon) med flere. Till bevis för denna mägtiga egenskap innom Växtriket, har pâ 1780 talet sjelfva Ràgen, en annuel Växt ibland Sảdes gräsen, gif. vit oss ett aldeles oförmodadt och besynnerligt exempel. Sedan den samma redan kommit i ax, frös den aldeles bort 


\section{) $27 \quad 1$}

under en uti Juni mânad infallande sträng frost natt; tmen växte sedan up igen ifrân rçen och gaf icke allenast nya ax, utan äfven mogen, ehuru svagare säd före hösten. Den andra omstandigheten är en föròkad och starkare Dragnings. kraft af de födancle ämnen under frö sãtlningen. Dragningskrafien måste under frürednings-perioden vara staikare, till ändamålets vinnande, än förut. Likasom bladen, måste blommans utvekling göra denna dragningskraft förökad, icke allenast för sjelfva blommans underhâlI, ułan ännu mera för fiugtens fullkomnande. Uti alla ofrugtbara blommor (steriles) forvissna blomfouret, hlomkronan, hanarne och sjelfva honan snart, samt affalla; dâ deremot uti befrödade blommor honan sväller, och med hvar dag påskyndar fröhölstrets tillväxt.

En starkare befrugtning hos honan utaf hannarnes fra mjöl torde afven ej ringa bidraga, att òka dragningskrafter. Man har sett af sükre rön, att dả honan på Eken med konst blifvit pudrad ined mycket frö mjöl, hafva de derefier blif. vande Allon varit större, frugtbarare och gifvit starkare Ekar. Persianerne pudra derföre altid honorne pả sine Dadel-trän, hvaraf Dadlarne blifva mycket större, än uti östra Jndien, der fröredningen lemnas ât naturens egen okonstlade omsorg och der frugterne blifva ganska små. Om antingen Jnsekters Larver fürära trädens blad, eller man på försòk vill afplåcka dem, skall man snart märka, att saftens upstigande för: minskas, och att ẹt sålant träd, antingen till flere grenar, eller tielt och hallet dör. ut, oaktadt dess hela bemódande, att frambringa nya blader. 


\section{17.5}

Vantigen htomstra och befröas de mäste Växter under den varmaste ârstiden, sâ att värmen icke ringa bidrager till denna starkare dragningskraft af födo-ämner ifrân roten, ända rill Vaxtens yttersta ändar. Att frö-redningen för sine störe behof drager till sig bảde flere och andre ämnen, än bladen och grenarne, tyckes med skäl kunna slutas deraf, att jorden aldramäst mattas, dâ ett och samma säde nytijas flere gånger à rad. Ett omväxlande utsäde lyckas bättre, emedan det sannolikt finner andre för sig tjänlige och af förra sädet obegagnade fö̀lo.ämnen.

Besinnar man tillika att en Växt, innan den löper i blomma, är mindre till sit omfảng, och förökas uti storlek, ofıa dubbelt eller mer, dả den gåıt i blomma, så faller det ganŁka naturligt, att denna förokade tillväxt, förenad med en starkare dragningskraft, fordrar större förrâd af fïda och un. derhâll ifràn jorden, hvilken foljagtelig̣en kommer, att mera förlora af sitt kol-ämne och sine oljagtige beståndsdelar, samt altså, att mera mattas och utmagras. Råg-brådden är orn vả. ren obetydlig i jämförelse med en Rảg-âker, som mognarsitt frö, till hvilket all näring så synes dragas, att blad och hal nn alldeles förtorka i samma mohn, axen förstoras, mogna och blifva tunga. Alla annuella växter framvisa denna syn âre ligen och de tu-årige på andra ảret, då de löpa i blomma, gifva frön och sedan försvinna. Mat-jorden förlorar sảledes under all fröredning mycket mera af sine födande delar, sitt kol.ämne, sin oljagtiga bestândsdel och de salter, som förena 


\section{) $\quad 29 \quad 1$}

dem med vatn. När man med ornsorg väl.gndi en Trägårds säng, så skïrdar man fijrsta ảret den storsta gridan af den svarta maijorden. Antra âret synes samma jord redan ble. kare och afkasmingen blifver nảgre procent mindre. Det tredje och foljande áren gifva skorden ännu ringare. Slute. ligen blir jorten oldeles grả stmt Mat jorden synhart förminskad Mat jorden forminskas salunda ydligen med hvarje år. gìng, dels lerigenom, alt den ned sin olja och sălta ingâtt i de sâdde nch updragne Vaxter, dels derigenom, alt dess flygtigare delar i luften bortdurstat, ty äfven uran säde kan Matjordens fodande egerrskp, af luftens och Solens attraction, gå forlorade, och jorden deraf utmagras.

18. $\$$.

Den Chemiska Analysen uptäcker väl till pricka Mat. jordens alla bestândsclelar. Den förmår äfven noga utstaka, hvad jorden innehâller före ett utsảde, och hvad den innehåller-efter slutad skörd; men deraf kan aldrig upgöras nảgon bestämd och rigtig beràkning, hvad en Växt af jorden åtnjutit, emedan mycket af jordens bestảndsilelar, igenom luf. tens åverkan bortdunstat, utan att komma det sådda till godo: och sjelfva Växten utur luften dragit till sig mycket, som icke förut befunnits i jorden, samt äfven vatnet och regnet medfört mångfaldige födande ämnen, hvilke en anstäld che. misk undersökning icke kunnat uptäcka. Denna dragning utur luften är grunden för alt Träde, under hvars hvila Åkerjordensäges hämta, och otvifvelaktigt hämtar nya krafter 
för nytt säde. Desse krafter kunna icke tilskrifvas nágon gödning af matjord, om ingen ny gödning pả åkren utföres, utan af de ämnen, som Luft och Sol meddela. Saltpetter fin: nes icke i sjelfva luftkretsen, men luftens attraction till ijän-

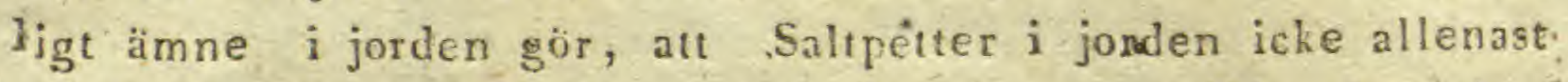
af sig sjelf beredes, utan äfven igenom särskilde houstige anstalter, till större förråd, kan frambringas,

\section{9. §.}

Det rön med Pil-trädet, som Helmont anstalt, och som förut blifvit anfürdt, tyckes väl kunna visa, att vatn ärett hufvudsakeligt och aldeles oumgängeligt födoàme för Växt. rikets alster; men den slutsats, som deraf drages för ringhe. ter af matjordens tilskntt, synes mindre säker. Att mato jordens egna beståndsdelar, och i synnerliet Kol ämnet, in: gâ uti Växternes Suğrör, och meddela en lögre grönska, jünte en starkare Växt, är ögnnskenligt och besannas af all väl gö slad jord. Färgade vatn, hvar med Växter blifvit vatnade, hafva äfven upstigit i deras rör, samt sâlunda medfört äfven det färgande ämnet och bestyrkt denna sanning. Ornkring London, der de idoge Trägårdsmästare hämta innom ãret en sjufaldig gröda af sin jord, känna de ganska väl, att ymnig vatning icke är ensam tilräckelig, att frambringa denna ri kelom, utan att dertill äfven fordras en ofta förnyad göd. sing med brunnen och väl blandad mat jord. 


\section{$3 I$
$20 . \S$}

Af de anförde rön och erfarenheter kan således inses, att mat. jordens finare Kol.ämne, uplöst uti vatn och dermed förenadt, àr Vàxternes förnämsta födo. ämne, att detta under Växtens filväxt måste under olika perioder förminskas, och att den bärande jorden i samma moln måste förlora sin drifvande förmåga, som hon, utan att njuta ny ersättning, beröfvas det närande ämnet. De phygiske och chemiske rön, som till uplys. ning i detta ämne anställas, böra ske med varsamhet, och de slutsatser, som deraf dragas, göras med mycken försigtig. Let. Utslagen måste altid blifva olika viıl en sådan undersök: ning, först $\mathrm{i}$ anseende till flerfaldigheten af de $\mathrm{i}$ jorden inblandade ämnen och sedan $\mathrm{i}$ anseende till olika myckenhet af hvarje slag i olika, fetare eller magrare jordmohn, äfven som efter Växtens olika ståndplats pả berg, höjder, â sumpig mark, vid hafsstränder, i lugn eller blâst, i skugga eller öppet Sol-sken,

$$
\text { 2I. } \S .
$$

Uti jordens sköte söker man förgàfves de bestândsclelar, som finnas i ett fulmogit frö eller i frugten. Den stärkelse, som utgör största delen af Sädeskornet och det behageliga sockerämnet, som prässas utur såcker.röret, äro icke sâdane uphämtade ifrản roten, utan en tilverkning uti Växtens egna Rör, tildanade af den outgrundeliga lifskraft, som en allvis Gud behagat gifva ât hvarje lefvande varelse, och som ännu ingen dödlig kunnat efterhärma med all sin spitsfundiga up. finnings förmåga. 


\section{) $32:($}

Narturens operationer äro allid mângfaldige och mânge đess hemligheter för menniskan ännu okände. Skaparens oräknelige verks betraktande har längst af alt Lärdt blifvit för. summadt. - Naturens kännedom, grunden och modren för ah hushållning och de fläste konster, raknar knapt ett ârhundra. de sima Anor. De Lärdas yrken hafva haft länge en helt annan rigtning, än Naturens kännedom och de Lárdas visdom har sällan eller fóga hunnit utvidga sig till kunskapen om Skaparens underbara verk, som tolka Hans vishet och all. makt. Den tid synes dock nalkas dả Naturens kännedom skall upmuntras, understödjas och belönas: då hushảllning nch kanster, som grunda sig pá denna kunskaps gren, skola upkamma, grönska och gagna: dả välmâga och sällhet skola spridas och ökas; dã det nyttiga och gagnande skall värderas, beforIras, högagtas. 